Article

\title{
The Silk Route from Land to Sea
}

\author{
Jack Weatherford \\ Professor Emeritus, Macalester College, St. Paul, MN 55105, USA; Jack.M.Weatherford@gmail.com
}

Received: 11 January 2018; Accepted: 30 March 2018; Published: 2 April 2018

\begin{abstract}
The Silk Route reached its historic and economic apogee under the Mongol Empire (1207-1368), as a direct result of the policies of Chinggis Khan (Genghis Khan) and his successors. Because the land network proved inefficient for the amount of goods needing transport from one part of the empire to another, the Mongols expanded the Silk Route to ocean shipping and thus created the first Maritime Silk Route. The sea traffic initially expanded the land routes but soon strangled them. With the expansion of the Maritime Silk Route through the fourteenth century, the land connections reverted to local networks and lost their global importance.
\end{abstract}

Keywords: Maritime Silk Route; Maritime World Order; Mongol Empire; Chinggis Khan; Khubilai Khan; Marco Polo; gerege; ships; ports; Ming dynasty; Yuan dynasty; Riverine Silk Route; Zhou Daguan; Khmer Empire

When Marco Polo, his father, and his uncle embarked from Venice in 1271, they first traveled to Persia, seeking to ship from Hormuz to China by sea (Polo 2016). Although both China and the Persian Ilkhanate were ruled by Mongols, such an ocean voyage was not yet possible. Instead, they had to travel via a series of caravans over the traditional Silk Route. By the time of Marco Polo's arrival at Khubilai Khan's capital of Khanbalik (now Beijing) around 1274, China, under the Mongol Yuan dynasty (1271-1368), had already become the world's first superpower. The rulers of the Yuan Dynasty controlled all the territory contained in modern China and received at least nominal submission from the Golden Horde ruling Russia, the Mongol Ilkhanate of Persia, and a string of countries and city states in between. Beginning with Chinggis Khan (Genghis Khan), the Mongols conquered the largest empire hitherto known in world history (Juvaini 1958). After the defeat of the Jin Dynasty in northern China in 1215, Chinggis Khan quickly began the systematic extension of control over the Silk Route and the conquest of its cities, which he placed under the rule of his daughters while his sons led the army continuously westward (Weatherford 2010). The conquest of the Silk Route indicated a decisive change in the military and political strategy of Chinggis Khan from raiding and looting sedentary populations in China to control of the trade that constantly moved along the Silk Route. Control of trade in the newly emerging modern world proved more remunerative and important than the control of production alone.

In addition to its role in commerce, Chinggis Khan clearly recognized the importance of the Silk Route as a means of reconnaissance and spying. Merchants proved the ideal spies, and through them he gained extensive knowledge of distant lands, their products, political squabbles, marriages, and the routes that connected their cities. In addition to service as spies, merchants became envoys and translators for the Mongol army. Chinggis Khan then turned the information about the Silk Route into one of his most important assets, and he used the network of routes as his means of invasion.

\section{Mongol Trade Corporation}

Although the empire was founded on some eight decades of military conquest from roughly 1210 until 1290, it was sustained for the next century by commerce along the Silk Route. In many ways, the Mongol Empire became the Mongol Corporation because of an unusual economic organization 
introduced by Chinggis Khan after his conquest of the Silk Route. Rather than merely dividing territory among family members, the entire Altan Urug (Golden Lineage) owned the entire empire in common. To make sure that they all derived benefit from the whole empire, each received the equivalent of modern corporate shares, called khubi in Mongolian, entitling each member of the royal family to a portion of the tribute from every part (Weatherford 2004, p. 290). Thus, the Mongols in China received shipments of furs, silver, amber, and soldiers from Russia; steel, medicines, musical instruments, jewels, spices, and gold embroidered damask from Persia; and high-quality paper, otter skins, and horses, from Korea. In turn, the Mongols in China sent the Golden Horde of Russia and the Ilkhanate of Persia ample supplies of silks, porcelains, almanacs, paper money, medicines, and other Chinese luxuries. The Mongol Ilkhan of Persia claimed the produce of 25,000 households of silk workers in China, which was ruled by his brother Khubilai.

The shares included not merely trade goods but also a claim on the labor of a specified number of craftsmen of various types. The Ilkhan also owned valleys in Tibet, and he had a claim on a share of the furs and falcons of the northern steppes, and, of course, he had pastures, horses, and men assigned to him in the homeland of Mongolia itself. Each lineage in the Mongol ruling family demanded its appropriate share of astronomers, doctors, weavers, miners, and acrobats.

Khubilai Khan owned farms in Persia and Iraq, as well as herds of camels, horses, sheep, and goats. An army of clerics traveled throughout the empire checking on the goods in one place and verifying accounts in another.

This unusual form of corporate ownership demanded the constant speedy and reliable transport of products and people throughout the year. The unprecedented flow of goods being transported via the Silk Route gave it an importance surpassing all previous eras. The Silk Route was not suited for a massive increase in trade. The movement of such quantities of materials required radical reform of the Silk Route.

Since the Roman times, a rudimentary system of trade existed along the Silk Road as goods moved from one oasis to another, from one city to another, from one kingdom to another. The goods frequently changed hands, which made the process not only slow but also expensive since every government entity extorted its own tariffs from the merchants and often required a change of personnel, merchants, and transport animals to benefit its own community.

Chinggis Khan did not invent this trade network; in fact, he followed many of these routes on his conquest because they led from one major city to another. Through a series of structural reforms, Chinggis Khan transformed this maze of local routes into a super highway in which goods, people, and information traveled at unprecedented speed and quantity. First, he and his successors improved the infrastructure. They dug wells, built bridges, made roads, and, perhaps, most importantly, created a series of stations where merchants could obtain horses, guides, food, lodging, and exchange their money or precious metals for Mongol paper money, which could be easily transported and guaranteed for use throughout the empire.

To maintain these posts and the approximately 400 horses assigned to each one, Marco Polo says that the khans built villages around them for the people to live and grow foods to support the system. With perhaps a little more enthusiasm than accuracy, he describes them as not merely "beautiful" and "palatial" but with "silk sheets and every other luxury suitable for a king." To promote trade along these routes, Mongol authorities distributed an early type of a combined passport and credit card. The Mongol gerege (usually known in the West by its Persian name paiza) was an oval tablet of gold, silver, or wood larger than a man's hand, and it would be worn on a chain around the neck or attached to the clothing. Depending on which metal was used and the symbols such as tigers or gyrfalcons, illiterate people could ascertain the importance of the traveler and thereby render the appropriate level of service. The gerege allowed the holder to travel throughout the empire and be assured of protection, accommodations, transportation, banking services, porters, fresh horses, and exemption from local taxes or duties. 
He simplified the labyrinth of trails and roads into a few major routes, and, in some cases, this required the destruction of whole cities that he considered parasites on the trade of the Silk Route. He massacred or dispersed the population and destroyed cities such as Merv, located in modern Turkmenistan, so that they could no longer divert traffic, harass it, or tax it. The Mongol destruction of these parasitic cities and their irrigation systems required tremendous organization and labor, and was not something undertaken merely for revenge or barbarian ignorance without a strategic purpose. Removing these barriers to trade, Chinggis Khan made the Silk Route faster and more efficient and provided pastures for the animals needed in this improved trade system.

By fundamentally altering the structure of the Silk Route, the Mongol emperors from Chinggis Khan to Khubilai Khan changed the commercial and economic structure of Eurasia. In addition to introducing banking and paper currency, they abolished tariffs and all forms of local taxes on commerce. They officially raised the status of merchants from the lowest class to a position equal to that of Confucian scholars and guaranteed them protection and free passage throughout the empire. They granted envoys the same privilege and protection even if the Mongols were at war with their home country.

Merchants, missionaries, and ambassadors traveled these roads often as part of large caravans transporting trade goods and tribute. To encourage this practice, Ogodei Khan, son and successor of Chinggis Khan, often paid up to ten times the asking price merely as a form of advertisement to entice merchants from lands beyond Mongol control to deliver even more types of goods along the route (Juvaini 1958).

For the first time, not only merchandise flowed along the Silk Route, but individuals could make the entire journey from Europe to China and home again without fear of robbery, harassment, or capture. The Franciscan monk Giovanni da Pian del Carpine of Italy and Benedict of Poland traveled this route from Italy to Mongolia between 1242 and 1247 (Sinor 1957). In 1253, William of Rubruck of Flanders set out on the same journey, representing King Louis IX of France (Jackson 2009). Kings and sultans from across Central Asia traveled the well-guarded routes to the Mongol court at Karakorum in Central Mongolia.

In 1241, after the Mongols annihilated the European knighthood in Poland and Hungary, they moved several thousand Saxon miners along the Silk Route to work in mines and make weapons in northern Asia (Allsen 2014). Later that year, the speed with which the Silk Route operated under Mongol control was demonstrated when Ogodei Khan died in December, and the news traveled to Hungary by the end of January 1242. The riders covered about 4700 miles in six weeks, at the rate of nearly one hundred miles a day. That speed of information moving over such a distance was not achieved again until the spread of the telegraph and railroad in the nineteenth century.

This reformed and more efficient organization allowed Marco Polo to travel the Silk Route from Venice to Khanbalik and to return home under Mongol protection and without interference. Thousands of other explorers, adventurers, mystics, pilgrims, kings, and envoys followed, not only from Europe but from southern Asia and the Muslim Middle East as well. Near the end of the Mongol Empire, Arab explorer Ibn Battuta arrived in China in 1345 and traveled to the Mongol capital (Dunn 2012).

Silk Route traffic always moved two ways. In addition to the European merchants and ambassadors who traveled from Europe to the Mongol court, the Mongols also dispatched representatives along the Silk Route to meet the Pope and rulers of France, England, Byzantium, and the city states of Italy in pursuit of alliances and trade. The most famous was Rabban Bar Sauma, a Christian priest from China, sent by Khubilai Khan, who traveled to the main courts of Europe in 1287-1289 (Montgomery 2006).

The fourteenth century, known as the Pax Mongolica, was described, with obvious hyperbole, as so peaceful and efficient that a virgin could walk from Russia to China with a pot of gold on her head without fearing harm. 


\section{Maritime Silk Route}

Khubilai Khan perceived clearly that products could be moved more easily, in greater quantities, and cheaper by water rather than across land. He restored Chinese canals, and he expanded the use of rivers in a major strategic extension of the Silk Route. In 1281, he launched a major expedition to discover and map the source of the Yellow River, which the Mongols called the Black River. Scholars used the information to make a detailed map of the river. The expedition opened a route from China into Tibet, and the Mongols used this as a means of including Tibet and the Himalayan area in the Mongol Post system and thereby in the expanded Silk Route.

The increased importance of water routes extended beyond the Chinese rivers. To reach the markets of Europe more directly, without the lengthy detour through the southern Muslim countries, the Mongols encouraged foreigners to tie directly into the traditional land-based Silk Route by creating trading posts on the edges of the empire along the Black Sea. Although the Mongols had initially raided the trading posts, as early as 1226, during the reign of Chinggis Khan, they allowed the Genoese to maintain a trading station at the port of Kaffa in the Crimea, and later added another at Tana (Ciocîltan 2012). Similar policies included water routes across the Caspian and Aral seas as well as a variety of rivers. To protect these stations, on land and water, the Mongols hunted down pirates and robbers. In the Pratica della Mercatura (Practice of Marketing), a commercial handbook published in 1340, the Florentine merchant Francesco Balducci Pegolotti stresses that the routes to Mongol Cathay are "perfectly safe, whether by day or by night (Pegolotti 2012)."

Gradually, the steppe-bound, horse-mounted Mongols began to see the importance of water transportation as an adjunct to the land routes. The greatest change in Mongol Silk Route policy came with the interminably slow conquest of the Southern Song dynasty (1127-1279) that clung to power in the south of China.

At the time of the Mongol conquest, the Southern Song Dynasty had already developed an extensive trade network, but since commerce was beneath the dignity of educated Chinese Mandarins, the business was left largely in the hands of Arab, Persian, and Indian merchants. For the Southern Song emperors, ships were not for commerce but as defense against the Mongols in a Maritime Great Wall of ports, canals, ship yards, and supply chains, which delayed the Mongol victory in the south for half a century. As late as 1250, the Mongols still used rafts and inflated sheep skins to cross rivers. However, within twenty years, Khubilai Khan incorporated the most sophisticated naval techniques and had a large, essentially Chinese, navy under the command of Mongol officers. Unlike the defensive navy of the Song, the Mongol navy combined a variety of Chinese tactics with Mongol war strategy to create a powerful, aggressive navy including many smaller but more agile craft. After another nearly two decades of constant Song defeat in naval battles and their retreat southward toward Vietnam, the Mongols finally defeated the remnants of the Song navy in 1279 and incorporated its ships and sailors into their own military (Lo 2012).

Chinggis Khan had built the greatest land power in history, but by the time Khubilai Khan formally united China in 1279, the Mongols controlled the most powerful navy in the world, and he decided to use it, as the Mongols had used all their prior resources, for conquest. A few of the sea invasions proved successful such as the conquest of the sparsely populated and not well-developed Sakhalin Island and the mouth of the Amur River (Walker 2006, p. 133). Despite assembling the greatest armada to set sea prior to World War II in the twentieth century, most of the expeditions ended not merely in failure but in disaster. Only the hard-fought sea invasions of Sakhalin Island, which began in 1264, and Jeju Island, completed in 1273, proved successful, but they were slow conquests. Nevertheless, these victories encouraged planning for more sea invasions. After his failure to conquer Japan in 1274 and 1281, Vietnam three times between 1258 and 1288, and Java in 1293, Khubilai Khan's ministers became increasingly skeptical of the possibility or the purpose of these foreign invasions. When the elderly emperor contemplated yet another set of invasions of coastal India and Thailand, some of his ministers pointed out the obvious: "These are small and distant countries. Of what benefit 
would their conquest be to us? To launch a war would risk the lives of our people for no useful purpose. It would be better to send envoys to advise them (Lo 2012, p. 286)".

Late in life, Khubilai Khan seemed to realize that, if he could be master of the sea, he did not need to expend money and men invading to occupy distant lands. By controlling their sea commerce, he ruled them. In assembling the largest navy in history, he had created a massive infrastructure to build and supply ships and to transport men, grain, weapons, and other goods over vast distances. China ruled the Silk Route of the Sea, but it did not yet control its rich resources.

Unlike the Song resistance to commerce, under Khubilai Khan, trade, based on the Mongol corporate system of shares, was a government monopoly, overseen and controlled by officials at every level. While initially weakening the power and wealth of the merchants, the policy created a much stronger and extensive financial and economic system, as illustrated most clearly by the introduction of a single system of Chinese metal coins and paper money across South Asia. Chinese and foreign merchants still profited, but they did so under the control of government and not as private enterprises.

Mongol hegemony in Asia had the same impact on the sea lanes as on the Silk Route on land. Prior to the Yuan dynasty, oceanic commerce proceeded slowly from port to port, constantly changing hands with local merchants along the way and often paying excessive taxes. Under such a system, only luxury goods could be transported, and their cost was greatly inflated by the repeated transactions, making them available to only the most privileged part of the elite. As the Mongol royal family, stretched over such a large area, grew from a small core of closely related individuals into an aristocracy of several thousand, the volume of goods needing transfer also grew at the same rate. To meet this growing demand, they first made war on the pirates to make the routes safe. They built marine bases on various small islands, organized large fleets for protection, and they used pigeons to communicate between ships. With safer seas, the Chinese navy reduced the number of ports needed and the number of times goods had to be exchanged or taxed. The system worked faster.

The Mongols protected the ocean route from the southern ports of China to the port of Hormuz in Iran and on to the Arabian coast for pilgrimage to Mecca. The sea lanes functioned not so much as an alternative to the land route but as a massive and unique extension of it. The southern route was the most important, but another route stretched past Korea and as far north as Siberia and included Japan and Okinawa, although they had not surrendered to the Mongols.

Between the beginning of Marco Polo's overland journey to China in 1271 and his return to Venice by sea in 1295, China suddenly became history's first naval superpower. Twenty-four years after the start of his journey eastward, Marco Polo was able to travel home under the protection of a Chinese fleet of fourteen ships that sailed from Zaitun in southern China to Hormuz in southern Persia. The Polos had travelled four years to reach China over the Silk Route on land, but only two years to return by the Maritime Silk Route. On the way home, they spent two years exploring the lands of newly declared vassals of the Great Khan along the route across the South China Sea and Indian Ocean from China to Iran.

After unifying China, the Mongols began shipping grain by sea from the south to the north, and by 1329 , this had grown to hundreds of thousand tons annually, far greater than the land roads of the Silk Routes (Needham 1971, p. 478). Marco Polo described the Mongol ships as large four-masted junks with up to 300 crewmen and as many as sixty cabins for merchants carrying various wares. According to Ibn Battuta, some of the ships even carried plants growing in wooden tubs in order to supply fresh food for the sailors. Khubilai Khan promoted the building of ever larger sea-going junks to carry heavy loads of cargo and ports to handle them. They improved the use of the compass in navigation and learned to produce more accurate nautical charts.

Though the Vietnamese kingdoms of Dai Viet and Champa had repulsed the Mongol naval invasions on land, they recognized that they could not compete with Mongol power at sea. To be at war with Khubilai Khan was to be denied access to sea commerce; they voluntarily, but usually only formally and nominally, submitted to Khubilai and became Chinese tributary vassals but without accepting Mongol officials to rule over them as had been demanded on the land Silk Route. 
Their submission meant that they joined the Mongol maritime monopoly and could participate in its vast network of trade, not only with China, but throughout the region. One by one, kingdom after kingdom across the South China Sea and as far as the coast of India did the same- the Khmer Empire of Cambodia, Sukhothai Kingdom and Chiang Mai of Thailand, and smaller states from the Malay Peninsula to Ceylon and the eastern coast of India. Within the span of Marco Polo's seventeen-year sojourn, China, by means of trade and control of the seas, became history's first maritime super power.

The era of Chinese naval hegemony produced an explosion in trade that rivaled and then far surpassed the famed Silk Route of caravans across the interior of Asia. Ships carried far more than camels could, and much more cheaply. The new vessels' unprecedented size soon flooded the imperial court in Beijing with exotic and extravagant goods. In addition to the array of luxuries such as silk, jewels, and precious metals transported on the traditional Silk Route, ships brought an immense diversity of bulk commodities such as dates, saffron, peaches, carpets, porcelains, spices, ivory, musk, velvet, wax, batik, pearls, coral, tiger skins, turtle shell, rhinoceros horn, crocodile leather, peacock feathers, perfume, sandalwood, agarwood, ambergris, tin, glass, damask, swords, dyes, books, and sacred relics of the Buddha, including one of his teeth. Even live elephants, rhinoceroses, parrots, and other exotic animals of the south began to arrive at the Chinese court. In turn, China sent a smaller variety of items-principally silks, satins, porcelains, lacquer work, manuscripts, and jade—but they produced them in unprecedented quantities. Some of them were traded as far as Europe and Africa.

\section{Riverine Silk Routes}

After the death of Khubilai Khan in 1294, his successor Temür Öljeytü Khan radically changed the function of the powerful Mongol navy. In a major and more efficient division of labor, he ended his grandfather's government monopoly and allowed more freedom for merchants, Chinese as well as foreign under protection of the now very international Chinese navy. He also abandoned the military ambitions of the earlier Mongol emperors and replaced it with systematic deployment of diplomatic missions designed to propagate a more peaceful vision of the Mongol empire, specifically by stimulating and expanding the ocean trade into more remote inland areas.

Temür Khan further initiated the new policy to extend the Silk Route from the ocean, up the rivers near the Mongol routes. After only one year in office, he dispatched several trade expeditions. While many such expeditions are mentioned in the historic records, few are described in detail. Only the expedition up the Mekong River to the court of the aging, but still important, Khmer Empire was recorded in detail, but it provides extensive information on how such missions were organized.

After sailing from South China, a mission of Mongol military officers and diplomats led a group of officials more than four hundred miles up the Mekong and then the Tonle Sap rivers to reach the court of Khmer Emperor Indravarman III in Yashodharapura, better known today as Angkor Thom, located north of the more famous Angkor Wat. The Chinese clerk who accompanied them, Zhou Daguan, produced an extensive report of their year-long stay from 1296-1297 (Zhou 2007).

Zhou Daguan proved an astute observer of architectural specifics and information about dress, house styles, and public life. History abounds in political, diplomatic, and religious texts, but rarely do we have a document that makes the daily life of a distant era come alive-the glittering gold towers, fluttering banners, decorated performing elephants, buzzing flies, dancing apsara, wafting incense, masons chipping away at stones, the bustle of the market, slaves working the fields, fishermen casting their nets, monks chanting, and children frolicking in the river.

Most importantly, he reported on the types of products available and how the markets operated. In contrast to Chinese and Muslim ports where men controlled the markets, in the Khmer Empire, they were controlled entirely by women. Their products originated deep in the jungles and provided yet more variety to the littoral products. These included rosewood, beeswax, gamboge resin, dried fish, lac, chaulmoogra oil, kingfisher feathers, hops, tung oil, grasscloth, and a variety of medicines. Zhou Daguan included detailed information on the shipping of such products and how much could be transported in one junk. 
The trade in goods and technology was surpassed only by the great movement in population and concomitant cultural influences. Until this time, Southeast Asia had been primarily a cultural colony of India with people following Hindu, and in some cases Buddhist, religions, kings taking Hindu names, and writing in Sanskrit or in new alphabets derived from it. The changes induced by the rapidly expanding Mongol sea empire produced a hybrid Sino-Indian culture in the countries now known as Vietnam, Cambodia, Laos, and Thailand, eventually giving rise to its western designation of this area as Indo-China.

The profound effect of the inclusion of these hitherto interior and rather isolated kingdoms into the Silk Route trade network can most clearly be seen in their change of focus from agriculture to commerce. The Khmer Empire moved its capital several times downriver ever closer to the sea routes before eventually settling permanently at Phnom Penh at the confluence of the Mekong and Tonle Sap, a destination easily reached by ocean-going Chinese junks. Similarly, in the coming years, other agriculturally based kingdoms in the north of Thailand and Burma shifted their focus to the sea as the old kingdoms such as Sukhothai, Chiang Mai, Chiang Rai, and Pagan, were replaced by the less fertile areas more commercially convenient and closer to the sea such as Bangkok, and Yangon (Weatherford 2017).

\section{Decline of Silk Route}

Initially, opening the Maritime Silk Route expanded and augmented the land routes, but soon they began to rival and then choke off the traditional Silk route. Caravan size was always limited by the number of pack animals and by the availability of fodder; thus, trade moved according to the whims of weather. Still subject to weather, ships faced fewer limitations and had no necessity to carry fodder for animals. As the Maritime Silk Route increased steadily in volume and importance, the caravan routes from China to the Middle East and Europe declined in importance and gradually reverted to a stunted network of local routes connecting the inland cities, while commerce from Europe to China moved away from the continental interior toward newly thriving sea ports. The expanded Mongol Silk Route had produced the new world order of the Maritime Era.

As the Mongol rulers stretched over the breadth of Eurasia became ever richer, they became indolent, degenerate, and weak. Distant cousins who shared the same ancestry but had never met began to compete with one another. The Mongols of the Golden Horde in Russia formed closer trade alliances with the Mamelukes of Egypt than with their relatives in the Ilkhanate of Persia. The Ilkhanate gravitated more toward India than China, which had formed closer ties in Southeast Asia and displaced the Indians.

As suddenly as the Mongol Empire exploded onto the world scene in the thirteenth century, it imploded completely before the end of the fourteenth. Without the military might of the army on the land route and the navy on the sea route, the Mongols' great trade network collapsed. The Silk Route on land and sea dissolved like water poured onto sand.

The new Ming dynasty that expelled the Mongol rulers from China in 1368 initially sought to reassert its control of the sea through a series of major expeditions, the most famous of which were commanded by the eunuch admiral Zheng He between 1405 and 1433 (Levathes 1997). The Ming maritime revival brought the Chinese trade system to its zenith under the Yongle emperor who reigned from 1402 to 1424, but it proved to be only temporary. Impressive as Zheng He's giant flotilla was, no great naval power backed it. The dragon fleet was no more than a paper dragon. It had proven vastly expensive, and the Mongols in the north remained a constant threat for which the Ming emperors needed the money in order to build the Great Wall. Mongols and other Turkic tribes reasserted control over the land Silk Route.

Having failed to recreate the Mongol naval empire, the Chinese emperors after Yongle's death turned their country in the opposite direction. They closed the shipbuilding centers, withdrew all Chinese in foreign lands, destroyed the ships, closed the ports to all private trade, burned navigation charts, banned interaction with foreigners or the consumption of foreign products (Lo 1958, p. 168). 
They sought to return to a totally isolated and sealed Middle Kingdom. By 1433, China had become a closed nation almost totally self-sufficient and desiring virtually nothing from any foreign nation.

\section{European Attempt to Revive the Maritime Silk Route}

History, like nature, abhors a vacuum. The rise of the Ming Dynasty brought the Chinese Maritime Silk Route to an end, but, having been created, the Maritime Silk Route shrank drastically but would not disappear so quickly. The mercantile networks created under the Mongols could not be completely undone by the Ming closing of China. Although Chinese control collapsed, the maritime network survived, and other rising world powers immediately vied to replace the Chinese navy in the vacuum. At first Indians, Arabs, and Persians returned to their dominant role in trade, but no one of them asserted total control.

Europe had become dependent on Asian spices and other goods, and without the Maritime Silk Route, the flow of goods declined dramatically. The absence of Chinese ships at sea and Mongol armies on land forced the Europeans out of their isolation in a quest to revitalize the sea connections and thereby increase their flow of Asian goods. A great scramble began to assert control over the abandoned trade routes. Soon, sultans, maharajas, emirs, and warlords competed with Portuguese and Spanish explorers, Dutch, French, and British merchants, and pirates of all nationalities to control the trade of the Indian Ocean and South China seas, the most important shipping channels on earth.

When Christopher Columbus set sail in 1492 to reach the islands of the Indies and the court of Cathay, he carried as his guide his heavily annotated copy of Marco Polo's adventures and voyages in Asia. Unfortunately, he never knew that the Mongol empire had collapsed and no longer controlled China. In addition, the continental American landmass blocked his way, and he never reached his passionately desired goal of the rich spice islands of the Indies and fabled bazaars of Cathay.

Despite centuries of competition for maritime commercial control, no one country proved able to reassert hegemony over the whole of the Chinese network or match the naval power of the Chinese navy under the Yuan and Ming dynasties. Unable to replace or replicate the now defunct hegemony of China over the seas, the European countries began to carve it up into spheres of influence. Spain took the area around the Philippines and tried to invade Cambodia. Portugal claimed smaller outposts from India and the Malay Peninsula to East Timor and Macao. Great Britain annexed India and Burma. France took Indo-China, and the Dutch claimed the spice islands of Indonesia. The nationalist competition among the powers did more to disrupt the Silk Route on land and sea than the Mongol collapse.

However, the Silk Route never quite died. The importance of the Maritime Sea Route has continued for nearly eight centuries, and the movement of cargo container ships across the oceans today is the direct descendant of the ancient Silk Route. Railroads have replaced camel caravans and ox trains, and China is leading the quest to renew the former Silk Route across Eurasia. The next chapter in the history of the Silk Route is yet to be written. Once again, China may well be the one to write it.

Conflicts of Interest: The author declares no conflict of interest.

\section{References}

Allsen, Thomas T. 2014. Population Movements in Mongol Eurasia. In Nomads as Agents of Cultural Change: The Mongols and Their Eurasian Predecessors. Edited by Amitai Reuven and Michal Biran. Honolulu: University of Hawaii Press.

Ciocîltan, Virgil. 2012. The Mongols and the Black Sea Trade in the Thirteenth and Fourteenth Centuries. Translated by Samuel Willcocks. Leiden: Brill.

Dunn, Ross E. 2012. The Adventures of Ibn Battuta: A Muslim Traveler of the Fourteenth Century. Berkeley: University of California Press.

Jackson, Peter. 2009. The Mission of Friar William of Rubruck. Indianapolis: Hackett Classics. 
Juvaini, Ala-ad-Din Ata-Malik. 1958. Genghis Khan: The History of the World Conqueror. Manchester: Manchester University Press.

Levathes, Louise. 1997. When China Ruled the Seas: The Treasure Fleet of the Dragon Throne, 1405-1433, reprint ed. Oxford: Oxford University Press.

Lo, Jung-pang. 1958. The Decline of the Early Ming Navy. Oriens Extremus 5: 149-68.

Lo, Jung-pang. 2012. China as a Sea Power: 1127-1368. Hong Kong: Hong Kong University Press.

Montgomery, James A. 2006. The History of Yaballaha III and of His Vicar Bar Sauma. Piscataway: Georgia Press.

Needham, Joseph. 1971. Science and Civilisation in China, Vol IV: 3. Cambridge: Cambridge University Press.

Pegolotti, Francesco Balducci. 2012. La Pratica della Mercatura: Book of Descriptions of Countries and of Measures of Merchandise. Cambridge: Medieval Academy of America.

Polo, Marco. 2016. The Description of the World. Indianapolis: Hackett Classics.

Sinor, Dinis. 1957. John of Plano Carpini's Return from the Mongols. Cambridge: Cambridge University Press.

Walker, Brent L. 2006. The Conquest of Ainu Lands: Ecology and Culture in Japanese Expansion, 1590-1800. Berkley: University of California Press.

Weatherford, Jack. 2004. Genghis Khan and the Making of the Modern World. New York: Crown.

Weatherford, Jack. 2010. Secret History of the Mongol Queens. New York: Crown.

Weatherford, Jack. 2017. Khmer Ways. Mekong Review. April. Available online: https:/ /mekongreview.com/ khmer-ways/ (accessed on 30 March 2018).

Zhou, Daguan. 2007. A Record of Cambodia: The Land and Its People. Translated by Peter Harris. Chiang Mai: Silkworm Press.

(C) 2018 by the author. Licensee MDPI, Basel, Switzerland. This article is an open access article distributed under the terms and conditions of the Creative Commons Attribution (CC BY) license (http:/ / creativecommons.org/licenses/by/4.0/). 